\title{
Price Information and Bidding Behavior in Repeated Second-Price Auctions
}

\author{
John A. List AND JASON F. SHOGRen
}

\begin{abstract}
Examining panel data on bidding behavior in over forty second-price auction markets with repeated trials, we observe that ( $i$ ) posted prices influence the behavior of the median naïve bidder; (ii) posted prices do not affect the behavior of the median experienced bidder or the bidder for familiar goods; and (iii) anticipated strategic behavior wanes after two trials. The results suggest that while affiliation might exist in auctions for new goods, the repeated trial design with nonprice information removes the correlation of values and provides the experience that bidders need to understand the market mechanism.
\end{abstract}

Key words: auctions, bidding, experimental markets, price, valuation.

Auction theory has succeeded in converting abstract game theoretic insight into notable practical importance. This success is due in part to the use of laboratory experiments to test critical analytical ideas. The laboratory testbeds used to understand the operating incentives underlying the multimillion-dollar spectrum rights auction are a prime example. ${ }^{1}$ Another case is the use of lab auctions to value neoteric agricultural and commercial products prior to field marketing, that is, irradiated food products, safer food, growth hormone-treated meat and dairy products, vacuum-packaged meat, and fresh foods and produce. ${ }^{2}$ Since these new products could turn into significant markets within a few decades, the ultimate success of using lab auctions to reveal meaningful values rests on how well we understand the incentives that operate in the lab. ${ }^{3}$

Lab valuation auctions often frame these incentives by using $(a)$ a demand-revealing auction such as a single-unit, sealed-bid second-price auction; ${ }^{4}$ and $(b)$ repeated bidding

John A. List is assistant professor of economics at the University of Central Florida. Jason F. Shogren is the Stroock Distinguished Professor of Natural Resource Conservation and Management in the Department of Economics and Finance at the University of Wyoming. The authors thank the National Science Foundation and the U.S. Department of Agriculture for partially funding this research. They also thank Sean Fox, Glenn Harrison, Dermot Hayes, and Lisa Rutström, and two reviewers for helpful comments.

' See, for example, McMillian, and Plott 1997.

${ }^{2}$ See, for example, Buhr et al.; Hoffman et al.; Fox et al. 1994; Hayes et al. 1995; Melton et al,; and Roosen et al

${ }^{3}$ While no definitive estimate exists, some experts think that eventually most meats in the United States will be irradiated, which could create a billion dollar market (Hayes, pers. comm., March 1998).

${ }^{4}$ See Vickrey. over multiple trials with posted market prices. A repeated second-price auction provides experience to bidders who walk into these auctions cold. The information sent by a posted market price helps bidders learn about the market mechanism and the upper support of the valuation distribution.

The risk with repeated bidding, however, is that a person's private value may become correlated or "affiliated" with this upper support of values. Affiliation exists when one bidder who values the good highly increases the chance that other bidders will also put a high value on the good (Milgrom and Weber, McAfee and McMillan). ${ }^{5}$ Posted prices, so the argument goes, transform independent private values into affiliated values when prices signal potential common outside options or commonly perceived, but unknown, characteristics of the product (Harrison, Harstad, and Rutström)

This article examines how price and nonprice information affects private values, and whether a repeated trial design significantly biases values or corrects naïve expectations of the market. Examining panel data from over forty second-price auctions with repeated trials, we present three key results. First, the market price affects bidding behavior for unfamiliar products, as implied by affiliated private values. A dime increase in the posted

\footnotetext{
s Posted prices allow people to learn what some other bidders are doing. and thus open the doot for commonly shared social norms such as reputation within a peer group (see, e.g., Akerlof; Bikhchandani; Bikhchandani, Hirshleifer, and Welsh).
} 
Table 1. Summary of Panel Data Categories

Total

Data Category

Measure

Observa-

1. Naïve

2. Naïve

3. Informed

4. Informed

5. Ex Ante Familiar

6. Ex Ante Familiar

Price only
Price only
Price \& non-price
Price \& non-price
Ex ante knowledge \& price
Ex ante knowledge \& price

of Value

tions

price increases the median willingness to pay by about a penny, while a dollar decrease in price lowers the median willingness to accept the offer by half a penny. Second, the price effect dissipates when bidders receive nonprice information about the good or are familiar with the product before entering the lab. Third, evidence of strategic behavior independent of any price signal still exists; buyers start bidding low and sellers start offers high, and then bids quickly stabilize after one or two trials. These results suggest posted prices can influence bidding behavior for unfamiliar products, but the effect dissipates when people have nonprice information about the good or are familiar with the good.

\section{Data and Empirical Methods}

We use panel data from published and unpublished lab valuation experiments that used repeated trials of the second-price auction for familiar and unfamiliar products such as growth hormone food products and food safety (e.g., sandwiches with a risk of food-borne diseases-trichinella, clostridium, salmonella). ${ }^{6}$ All the experiments followed a common experimental design (see Shogren et al. for an example of the experimental instructions). For our purposes, three points are worth emphasizing. First, the experimental instructions made clear why it was in each subject's best interest to tell the truth when bidding in a second-price auction - a standard lab valuation procedure (see Hoffman et al.). Second, each experiment used a repeated trials design, in which only one trial was chosen at random as the "binding" auction-only the highest bidder purchased one unit of the good for the

\footnotetext{
${ }^{6}$ Data come from published and unpublished research on the value of food safety (Shogren et al.; Hayes et al. 1995, 1996) and new food products (Buhr et al.; Fox et al. 1995a,b, 1996, 1998). All data are available upon request.
}

second-highest price in the binding trial. The random trial feature allows people to learn about the market mechanism, without consuming the good after each trial. The random trial avoids complications of multi-unit demand and rapidly declining marginal valuation functions. Third, the second-highest price was publicly posted after each trial. The posted price provided subjects with market price information generated by the group interaction that would otherwise be unavailable in one-shot experiments. ${ }^{7}$

Table 1 presents the details of the six panel data categories: rows 1 and 2 represent naive willingness to pay (WTP) bids and willingness to accept (WTA) offers for unfamiliar products with posted second-price but without nonprice information about the product; ${ }^{8}$ rows 3 and 4 represent informed WTP bids and WTA offers for unfamiliar goods with posted price and nonprice information; ${ }^{9}$ and rows 5 and 6 represent ex ante familiar WTP bids and WTA offers for a familiar good (Snickers or Milky Way candy bars) with posted price.

We estimate the following model for the six categories of panel data:

$$
B_{i t}=\alpha_{i}+\beta P_{i, t-1}+\varphi_{t}+\epsilon_{i t}
$$

where $B_{i t}$ denotes median bid or offer in experiment $i$, trial $t ; P_{i, t-1}$ denotes posted price

\footnotetext{
Kagel (p. 521) notes that "standard noncooperative game the oretic models of auctions make no mention of the effects of price information following bid submission since most theory relates to single period auctions where such feedback would be irrelevant." Induced valuation experiments have not generated any systematic response between price information and bidding behavior (see Isaac and Walker; Kagel, Harstad, and Levin).

${ }^{8}$ Bids and offers in trial 1 were excluded since there was no posted price.

"Nonprice information was given between trials 10 and 11 in all treatments. Subjects were told, for example, the objective probability of becoming ill from consuming the typical food product, a description of the illness, and the symptoms and average medical costs of a mild case of infection. See Shogren et al. for an example of the information provided about the product.
} 
in experiment $i$ for trial $t-1 ; \alpha_{i}$ represents a fixed/random auction effect; $\varphi_{i}$ is a trial fixed/random effect; and $\epsilon_{i i}$ represents the contemporaneous error term. We use median bid to proxy for bidding behavior to avoid extreme outliers and overweighting random patterns of bidding behavior in the last few trials of experiments (see, e.g., Gregory and Furby). Auction effects, $\alpha_{i}$, control for characteristics that vary from auction to auction but are invariant over trials of the same auction, for example, unique characteristics of auctioned goods, the lab environment, and nuances of monitors and subjects. Trial effects, $\varphi_{t}$, capture variables that are invariant across auctions, and thus control for trends in subject behavior and market experience. Econometric estimates of equation (1) are obtained for both fixed and random effects models of panel data. $^{10}$

\section{Results and Discussion}

Table 2 presents estimation results of equation (1). ${ }^{11}$ Our first step is to choose the appropriate regression model. Diagnostics in table 2 lead us to reject the null hypothesis of homogeneous auction effects, $\alpha_{i}=0$, for all models at the $1 \%$ level, except for the ex ante familiar WTA model (which we reject at the $6 \%$ confidence level). Furthermore, we reject the null hypothesis of homogeneous trial effects, $\varphi_{t}=$ 0 , at the $5 \%$ significance level for each data category, except for the ex ante familiar WTA model. Taken together, the homogeneity tests imply that pooled ordinary least squares estimates are inefficient and may yield biased coefficient estimates. Also, Hausman tests $\left(\sim \chi^{2}\right.$ with 1 degree of freedom) of the null hypothesis of zero correlation between price and auction effects suggest that the orthogonality assumption is violated in all models except for the informed WTA model for unfa-

\footnotetext{
${ }^{10}$ Both estimation approaches control for unmeasured heterogeneity that pooled ordinary least squares ignores. Random effects estimates of equation (1) yields coefficients that are not conditioned on unmeasured auction effects, whereas fixed effects yields coefficients conditioned on the unmeasured characteristics. Fixed effects estimates are inefficient since they consider only the within-auction variation of bids. If the auction or trial effects are correlated with posted prices, however, random-effects estimates arè biased and inconsistent while the within-effects (fixed-effects) estimator remains unbiased and consistent. We use Hausman's test of orthogonality when comparing estimates from fixed and random effects models.

"We also ran regressions allowing posted prices to affect bids differently across trials. Overall, these results are similar co those in tables 2 and 4, and, for brevity sake, we do not present these results here. All regression results are available upon request from the authors.
}

miliar products and the familiar WTA for candy bars. Nevertheless, since random and fixed-effect estimates are economically similar, table 2 includes only fixed-effect estimates. ${ }^{12}$

\section{The Posted Price Affects Bidding Behavior for Unfamiliar Products}

Our estimation results in the top panel of table 2 suggest that the price effect does exist for unfamiliar products. Estimated coefficients (column 1) indicate posted prices affect the behavior of the median naïve WTP bidders facing unfamiliar goods (at the $1 \%$ confidence level). A dime increase in the posted secondprice increased the median willingness-to-pay bid by about a penny. Parameter estimates (column 3) for the naïve WTA measures for unfamiliar goods are similar but less severe in economic significance-if the posted price falls by one dollar the median offer falls by about half a cent. Absent information about the product, naïve bidders seem to rely on the signal sent by the posted second-price from trial $t$ when updating their bids, or offers, in trial $t+1 . .^{13}$

Is this tendency for prices to lead naïve bidders economically significant given that the unfamiliar products, sandwiches, would retail for about $\$ 4$ ? If the posted price increased by one dollar between trials 2 and 10 , the implied increase in median naïve WTP bid is about $8 \%$-about $2 \%$ of value. Large price spikes, however, were rare in the WTP naïve markets. The average posted price increased to $\$ 1.59$ (s.d. $=1.28$ ) in the late trial from $\$ 1.21$ (s.d. $=0.76$ ) in the early trial-resulting in a point estimate increase of $\$ 0.03$ in the median bid $(=\$ 0.38 \times 0.08)$, which is less than $1 \%$ of value. If we build a $95 \%$ confidence interval around the estimated coefficient, $\beta=0.08$, we see that the lower and upper bounds of the price effect are $\$ 0.01$ and $\$ 0.05(=0.38 \times 0.021$ and $0.38 \times 0.139)$, translating into about $0.02 \%$ and $1.3 \%$ of value. This price effect seems relatively modest. At most, about a nickel of the change in median bids is caused by posted prices, implying

\footnotetext{
12 Random-effects estimates are available upon request.

${ }^{13}$ In a completely different context (a test of how institutions affect preference reversals), Cox and Grether explored how individual bid: for lotteries were correlated with lagged market prices in a secondprice auction. They observe that bidders do alter their bids based on the posted market price, suggesting that people use the extra information sent by the price when forming bids.
} 
Table 2. Two-Way Fixed Effects Estimation Results for Bid Equation

\begin{tabular}{|c|c|c|c|c|c|c|}
\hline \multirow[b]{3}{*}{ Variable } & \multicolumn{4}{|c|}{ Ex Ante Unfamiliar } & \multicolumn{2}{|c|}{ Ex Ante Familiar } \\
\hline & \multicolumn{2}{|c|}{ WTP } & \multicolumn{2}{|c|}{ WTA } & \multirow[b]{2}{*}{ WTP } & \multirow[b]{2}{*}{ WTA } \\
\hline & Naïve & Informed & Naïve & Informed & & \\
\hline Constant & $\begin{array}{c}0.54 * \\
(0.05)\end{array}$ & $\begin{array}{c}0.67^{*} \\
(0.03)\end{array}$ & $\begin{array}{c}1.39^{*} \\
(0.05)\end{array}$ & $\begin{array}{c}1.29^{*} \\
(0.23)\end{array}$ & $\begin{array}{c}0.34^{*} \\
(0.03)\end{array}$ & $\begin{array}{c}0.36 \\
(0.32)\end{array}$ \\
\hline Price $_{t-1}$ & $\begin{array}{c}0.08^{*} \\
(0.03)\end{array}$ & $\begin{array}{c}-0.002 \\
(0.02)\end{array}$ & $\begin{array}{c}0.004^{*} \\
(0.001)\end{array}$ & $\begin{array}{c}-0.001 \\
(0.001)\end{array}$ & $\begin{array}{c}-0.04 \\
(0.06)\end{array}$ & $\begin{array}{c}-0.47 \\
(0.89)\end{array}$ \\
\hline $\mathrm{R}^{2}$ & 0.73 & 0.89 & 0.89 & 0.62 & 0.93 & 0.58 \\
\hline Adj. $R^{2}$ & 0.69 & 0.87 & 0.84 & 0.45 & 0.90 & 0.20 \\
\hline $\begin{array}{l}\mathrm{F}\left(\boldsymbol{\alpha}_{i}=0\right) \\
\text { (d.f.) }\end{array}$ & $\begin{array}{c}7.88 \\
(31,255)\end{array}$ & $\begin{array}{c}57.02 \\
(31,287)\end{array}$ & $\begin{array}{l}23.36 \\
(4,39)\end{array}$ & $\begin{array}{c}6.18 \\
(4,44)\end{array}$ & $\begin{array}{c}14.82 \\
(22,68)\end{array}$ & $\begin{array}{c}2.84 \\
(4,14)\end{array}$ \\
\hline $\begin{array}{l}\mathrm{F}\left(\phi_{t}=0\right) \\
\text { (d.f.) }\end{array}$ & $\begin{array}{c}3.50 \\
(8,246)\end{array}$ & $\begin{array}{c}2.27 \\
(9,277)\end{array}$ & $\begin{array}{c}5.25 \\
(8,30)\end{array}$ & $\begin{array}{c}2.42 \\
(9,34)\end{array}$ & $\begin{array}{c}3.03 \\
(3,64)\end{array}$ & $\begin{array}{c}0.50 \\
(3,10)\end{array}$ \\
\hline $\begin{array}{l}\text { Hausman } \\
\text { (d.f.) }\end{array}$ & $\begin{array}{l}25.84 \\
\text { (1) }\end{array}$ & $\begin{array}{l}2.80 \\
(1)\end{array}$ & $\begin{array}{l}29.22 \\
(1)\end{array}$ & $\begin{array}{l}0.82 \\
(1)\end{array}$ & $\begin{array}{l}30.10 \\
\text { (1) }\end{array}$ & $\begin{array}{l}0.72 \\
(1)\end{array}$ \\
\hline$N$ & 288 & 320 & 45 & 50 & 92 & 20 \\
\hline
\end{tabular}

Note: * denotes significant at the 0.01 level

* Dependent variable is median bid in trial $t$.

- Standad errors are in parentheses under coefficient estimates.

that a small percentage of overall variability is attributable to price changes.

In the WTA naïve regression, the average posted price falls to $\$ 9$ (s.d. $=7.21$ ) in trial 10 from $\$ 78$ (s.d. $=125$ ) in trial 2 . With the small regression coefficient estimate and the relatively large standard error for the WTA bids, the argument made for naïve WTP holds for WTA as well-the price-induced decreases are within the margin of error surrounding the average bid, suggesting an exaggerated fear of onerous quantitative bias for the goods considered herein. ${ }^{14}$

\section{The Price Effect Vanishes with Nonprice Information and Familiarity, but Bids Still Change}

Table 2 shows that the price effect disappears when the subject is given nonprice information or is more familiar with the product. Bidders seem to use price and nonprice information as substitutes when formulating their measure of value. Estimated $t$-ratios of -0.1 and -1.0 imply that the posted price affects neither the median-informed WTP bid nor the median-informed WTA offer at any conventional level of significance (columns 2 and 4).

\footnotetext{
${ }^{14}$ Note that prices and median bids are trending monotonically and not jumping up and down cyclically. This precludes the complaint that we are taking a "long" derivative by comparing posted prices from period 1 versus 9 rather than examining each period one by one and summing; e.g., the sum roughly approximates the whole.
}

This suggests that informed bidders treat the written word as a substitute for market signals. Bids and offers for the familiar candy bars reinforce this observation-posted prices do not affect WTP bids or WTA offers (columns 5 and 6) at conventional significance levels. In general, the more familiar a bidder is with the good before entering the lab, the less the posted second-price affects his or her behavior.

Although the price effect dissipates, table 3 shows that the median WTP bids and WTA offers in the early rounds differ significantly from those in the late rounds, regardless of treatment. For example, column 2 in table 3 shows that the average median-informed WTP bid increased to $\$ 0.72$ in the late trial from $\$ 0.58$ in the early trial. To test if median bids/ offers in the early trials equal the median bids/ offers in the later trials, we use a pairwise $t$ test of the null hypotheses, $\mathrm{H}_{\mathrm{o}}:$ bid $_{1}-$ bid $_{10}$ $=0$ for uninformed bids/offers; $\mathrm{H}_{0}$ : bid $_{11}-$ bid $_{20}=0$ for informed bids/offers; and $\mathrm{H}_{\mathrm{o}}$ : bid $1-$ bid $_{5}=0$ for ex ante familiar bids/ offers. The results in the final row in table 3 suggest that we should reject equality of median bids for each WTP treatment, implying that late bids are greater than early bids (negative $t$-values in table 3 ). For the WTA treatments, we also reject equality of median offers in all treatments-earlier offers are greater than offers from later trials. ${ }^{15}$

\footnotetext{
${ }^{15}$ As a consistency check, we also examined the behavior of the
} 
Table 3. Summary Statistics on WTP and WTA (Median Bids)

\begin{tabular}{|c|c|c|c|c|c|c|}
\hline \multirow[b]{3}{*}{ Variable } & \multicolumn{4}{|c|}{ Ex Ante Unfamiliar } & \multicolumn{2}{|c|}{ Ex Ante Familiar } \\
\hline & \multicolumn{2}{|c|}{ WTP } & \multicolumn{2}{|c|}{ WTA } & \multirow[b]{2}{*}{ WTP } & \multirow[b]{2}{*}{ WTA } \\
\hline & Naïve & Informed & Naïve & $\begin{array}{c}\text { In- } \\
\text { formed }\end{array}-$ & & \\
\hline $\begin{array}{l}\text { Mean of median bid } \\
\text { early trial }\end{array}$ & $\begin{array}{c}0.50 \\
(0.05)\end{array}$ & $\begin{array}{c}0.58 \\
(0.07)\end{array}$ & $\begin{array}{c}2.40 \\
(0.37)\end{array}$ & $\begin{array}{c}2.50 \\
(0.85)\end{array}$ & $\begin{array}{c}0.29 \\
(0.04)\end{array}$ & $\begin{array}{c}0.40 \\
(0.04)\end{array}$ \\
\hline $\begin{array}{l}\text { Mean of median bid } \\
\text { late trial }\end{array}$ & $\begin{array}{c}0.74 \\
(0.07)\end{array}$ & $\begin{array}{c}0.72 \\
(0.09)\end{array}$ & $\begin{array}{c}1.03 \\
(0.26)\end{array}$ & $\begin{array}{c}0.88 \\
(0.20)\end{array}$ & $\begin{array}{c}0.34 \\
(0.04)\end{array}$ & $\begin{array}{c}0.35 \\
(0.05)\end{array}$ \\
\hline $\begin{array}{l}\text { Bid contrast pairwise } \\
t \text {-test (d.f.) }\end{array}$ & $\begin{array}{l}-4.86 * * * \\
(31)\end{array}$ & $\begin{array}{l}-2.70 * * \\
(31)\end{array}$ & $\begin{array}{l}3.63 * * \\
(4)\end{array}$ & $\begin{array}{l}2.37 * \\
(4)\end{array}$ & $\begin{array}{l}-2.05 * \\
(22)\end{array}$ & $\begin{array}{l}2.93 * * \\
(4)\end{array}$ \\
\hline
\end{tabular}

Notes: *** denotes signiticant at the 0.01 level. ** denotes significant at the 0.05 level. * denotes significant at the 0.10 level.

"Standard errors are in parentheses under mean of the median bid.

"The null hypothesis of the bid contrast pairwise t-test is whether the median bidsfoffers in early trials equal the median bids/offers in the latter trials:

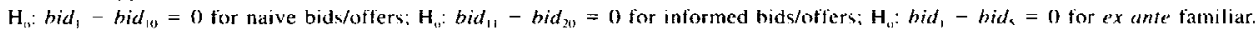

\section{Anticipated Strategic Behavior Wanes after Two Trials}

The results in table 3 suggest that informed buyers start their bidding low and informed sellers start their offers high. Although many factors may cause these observed phenomena, two plausible explanations are posted price effects and market experience. We delve further into this issue by examining the estimated coefficients of the trial effects, $\varphi_{t}$, from equation (1). As previously mentioned, trial dummies account for effects that are across-auction invariant but change over trials of any

second-price institution by measuring how lagged posted prices affect current posted prices. We re-estimated cquation (1) using the following model for the six categories of panel data: $P_{t}=\alpha_{i}+\beta P_{t,-1}$ $+\varphi_{i}+\epsilon_{t r}$ where $P_{i t}$ denotes posted price in experiment $i$, trial $t$; $P_{, t-1}$ denotes posted price in experiment $i$ for trial $t-1, \alpha_{t}$ represents a fixed/random auction effect, $\varphi_{,}$is a trial fixed/random effect, and $\epsilon_{\mathrm{Ir}}$ represents the contemporaneous error term.

The estimation results from the two-way fixed effects models are as follows:

\begin{tabular}{|c|c|c|c|c|c|c|}
\hline & \multicolumn{2}{|c|}{ WTP } & \multicolumn{2}{|c|}{ WTA } & \multicolumn{2}{|c|}{ Familiar } \\
\hline & Naïve & Informed & Naïve & Informed & WTP & WTA \\
\hline $\begin{array}{c}\text { Coefficient } \\
\text { of } P_{t-1} \\
\text { (t-ratio) }\end{array}$ & $\begin{array}{r}0.97 \\
(27.1)\end{array}$ & $\begin{array}{r}0.24 \\
(4.3)\end{array}$ & $\begin{array}{r}0.33 \\
(19.2)\end{array}$ & $\begin{array}{c}0.01 \\
(0.06)\end{array}$ & $\begin{array}{r}-0.09 \\
(-1.1)\end{array}$ & $\begin{array}{r}0.14 \\
(1.7)\end{array}$ \\
\hline
\end{tabular}

The results imply, for instance, that for each dime increase in posted price in trial $t$, price is expected to increase by $\$ 0.097$ in trial $t+$ 1 in the WTP naive model. In this model, the mean increase in price by trial is $\$ 0.04(\$ 0.38 / 9)$. The average posted price increased to $\$ 1.59$ (s.d. $=1.28)$ in the late trial from $\$ 1.21(\mathrm{s.d} .=0.76)$ in the early trial. This increase in posted price would induce an increase of approximately $\$ 0.04$ in next period's price $(0.97 * \$ 0.04)$. Through similar intuition in the other five models, our overall results suggest two points. First. institutional behavior is similar to bidder behavior-the price effect is dampened for informed bidders and is eliminated completely for familiar commodities. Second, a majority of the posted price increases in the natye models are due to previous price changes (as seen in the above example), and most trial effects are insignificant at conventional levels for these models. Alternatively, in the other models, much of the price changes can be attributed to experience. specific auction, controlling for any price effects. Hence, trial effects account for particulars such as market experience. Because most trial effects are not significantly different from zero, table 4 shows only the estimated early and late trial effects. The table also presents a $t$-test of trial-effect homogeneity across the early and late trials.

Estimates in table 4 suggest that we can reject the null hypothesis that the estimated trial coefficients in early and late trials are equal in all treatments at the $1 \%$ significance level (except for the ex ante familiar offers), where the null hypotheses are as follows: $\mathbf{H}_{0}$ : $\varphi_{2}=\varphi_{101}$ for uninformed bids/offers; $\varphi_{11}=\varphi_{20}$ for informed bids/offers; and $\varphi_{2}=\varphi_{5}$ for $e x$ ante familiar bids/offers. A negative $t$-value implies that the late trial effect is greater than the early trial effect, for example, for WTP naive, -3.35 suggests the trial coefficient of trial 10 is significantly greater than the coefficient of trial 2 . This result suggests that, irrespective of posted prices, bids tend to increase over trials. Standard $t$-tests of the trial coefficients from the WTA auctions imply the opposite-offers tend to decrease over trials.

Why would bids and offers change with experience holding posted price constant? One answer is that a Hawthorne-type effect is present - asking people to bid over and over makes them feel important, so they increase bids or decrease offers over time to please the monitor by meeting his or her perceived expectations of good bidding behavior. ${ }^{16}$ Anoth-

\footnotetext{
16. The classic Hawthorne effect exists when people behave differently because they are subjects in an experiment. The effect was first clearly identified in job pertormance experiments at the Hawthorne plant of the Western Electric Company. Researchers noted
} 
Table 4. Comparison of Early and Late Trial Effects

\begin{tabular}{|c|c|c|c|c|c|c|}
\hline \multirow[b]{3}{*}{ Variable } & \multicolumn{4}{|c|}{ Ex Ante Unfamiliar } & \multicolumn{2}{|c|}{ Ex Ante Familiar } \\
\hline & \multicolumn{2}{|c|}{ WTP } & \multicolumn{2}{|c|}{ WTA } & \multirow[b]{2}{*}{ WTP } & \multirow[b]{2}{*}{ WTA } \\
\hline & Naïve & Informed & Naïve & Informed & & \\
\hline $\begin{array}{l}\text { Early trial } \\
\text { coefficient }\end{array}$ & $\begin{array}{c}-0.13^{*} \\
(0.04)\end{array}$ & $\begin{array}{c}-0.09^{*} \\
(0.03)\end{array}$ & $\begin{array}{c}0.73^{*} \\
(0.19)\end{array}$ & $\begin{array}{c}1.22 * \\
(0.41)\end{array}$ & $\begin{array}{c}-0.03^{*} \\
(0.01)\end{array}$ & $\begin{array}{c}0.02 \\
(0.05)\end{array}$ \\
\hline $\begin{array}{l}\text { Late trial } \\
\text { coefficient }\end{array}$ & $\begin{array}{c}0.06 \\
(0.04)\end{array}$ & $\begin{array}{c}0.05 \\
(0.03)\end{array}$ & $\begin{array}{c}-0.39 \\
(0.17)\end{array}$ & $\begin{array}{c}-0.52 \\
(0.41)\end{array}$ & $\begin{array}{c}0.02 \\
(0.01)\end{array}$ & $\begin{array}{r}-0.03 \\
(0.03)\end{array}$ \\
\hline $\begin{array}{l}t \text {-test of equal trial } \\
\text { effects (d.f.) }\end{array}$ & $\begin{array}{l}-3.35^{*} \\
(246)\end{array}$ & $\begin{array}{l}-3.71 * \\
(277)\end{array}$ & $\begin{array}{l}4.27^{*} \\
(30)^{2}\end{array}$ & $\begin{array}{l}2.98 * \\
(34)\end{array}$ & $\begin{array}{l}-3.12 * \\
(64)\end{array}$ & $\begin{array}{l}0.95 \\
(10)\end{array}$ \\
\hline
\end{tabular}

Note: * denotes significant at the $1 \%$ level.

${ }^{a}$ Standard errors are in parenthesis under estimated trial coefficients.

${ }^{n} t$-tests are for the null hypothesis that the estimated trial coefficients in early and late trials are equal; $\mathrm{H}_{0}: \phi_{2}=\phi_{10} ;$ or $\phi_{11}=\phi_{20} ;$ or $\phi_{2}=\phi_{5}$, depending on treatment.

er intuitively plausible explanation is strategic behavior. Rational bidders begin prudently realizing that several trials exist - they begin by testing the market (Grether, Plott 1996). As one might do when buying or selling any good, buyers start low and increase bids, and sellers start high and decrease offers, to learn what the market will tolerate. With information, their expectations change along with bids and offers. This suggests some form of strategic behavior-bids increase and offers fall with repeated market experience, even for the informed and familiar bidders who are unaffected by posted prices. Nevertheless, given that the trial effects are not significantly different from zero after the first few trials in each auction type, results indicate that such strategic bidding only persisted for one or two trials, a result also observed in Shogren.

Combining regression results in table 2 with the intuition from the underlying trial effects in table 4, we attribute much of the change in median bids to market experience gained in the early trials. For example, if the gap between average WTP in the early trial and the late trial is approximately $20 \notin$ and at most $5 \phi$ can be attributed to a price effect, the remaining $15 \phi$ can potentially be attributed to what one might consider a typical bidding strategy of starting low and working up with experience, as one might expect to see in a real market.

\section{Concluding Comments}

One of the clearest lessons learned over the years from the lab is that the context of choice

that after they made changes in the workplace to monitor behavior, the workers felt more important and thus worked harder (see Roethlisberger and Dickson, Rosenthal and Jacobson, Benson). matters. Thus, knowing whether affiliation of private values exists in lab valuation exercises can help guide future work. Our results suggest that affiliated private values seem to exist in repeated second price auctions when people do not have ex ante information on the goodposted prices pull up median bids by about $1 \%$ of value for unfamiliar goods. Whether this is a cause for anxiety depends on the good. Highly competitive markets might welcome a $1 \%$ increase in the price of its product. When people know about the product or are given nonprice information, however, prices do not affect median bids, suggesting that private values are less likely to be affiliated.

These results have two pragmatic implications for lab valuation research. First, the affiliation of private values can be reduced, if not removed, by providing product information prior to bidding. Second, a few trials help people learn about the market mechanism. Some people might need the experience as it appears that they did not fully comprehend the strategic implications of the second-price auctions. This occurred despite experimental instructions that explicitly informed participants that $(a)$ telling the truth was the best strategy for bidding, and (b) only one trial was binding so that only one unit of the good was for sale for the entire experiment. Given these explicit instructions, subjects should have viewed an experiment as a set of one-shot auctions repeated many times (one trial selected at random to be binding) rather than as a repeated auction with multiple units that would force them to specify a single bidding strategy for all trials. Subjects might not have understood or trusted the instructions, or they might have tested the market with their initial bids to see what happens if this "best strat- 
egy" is ignored. Our data cannot reveal which strategy was prevalent, which suggests a direction for future lab valuation experiments.

[Received July 1998;
accepted January 1999.]

\section{References}

Akerlof, G. "A Theory of Social Custom, of which Unemployment May Be a Consequence." Quart. J. Econ. 94(June 1980): $749-75$.

Benson, P. "Hawthorne Effect." Encyclopedia of Psychology, vol. 2, 2nd ed. R. Corsini, ed., pp. 108-9. New York: John Wiley and Sons, 1994.

Bikhchandani, S. "Reputations in Repeated Second Price Auctions." J. Econ. Theory 46(October 1988):97-119.

Bikhchandani, S., D. Hirshleifer, and I. Welsh. "Learning from the Behavior of Others: Conformity, Fads, and Information Cascades." J. Econ. Perspect. 12(Summer 1998):15170.

Buhr, B., D. Hayes, J. Shogren, and J. Kliebenstein. "Valuing Ambiguity: The Case of Genetically Engineered Growth Enhancers." $J$. Agr. Res. Econ. 18(December 1993): 175-84.

Cox, J., and D. Grether. "The Preference Reversal Phenomena: Response Mode, Markets, and Incentives." Econ. Theory 7(April 1996): 381-405.

Fox, J., B. Buhr, D. Hayes, J. Shogren, and J. Kliebenstein. "A Comparison of Preferences for Pork Sandwiches Produced from Animals With and Without Somatotropin Administration." J. Animal Sci. 73(April 1995a):104854.

Fox, J., D. Hayes, J. Shogren, and J. Kliebenstein. "Consumer Acceptability of Milk from Cows Treated with Bovine Somatotropin." J. Dairy Sci. 77(March 1994):703-7.

Fox, J., J. Shogren, D. Hayes, and J. Kliebenstein. "CVM-X: Calibrating Contingent Values with Experimental Auction Markets." Amer. J. Agr. Econ. 80(August 1998):455-65.

-. "Experimental Auctions to Measure Willingness to Pay for Food Safety." Valuing Food Safety and Nutrition. J. Caswell, ed., pp. 115-28. Boulder CO: Westview Press, 1995b.

-. "Experimental Methods in Consumer Preference Studies." J. Food Dist. Res. 27(January 1996):368-78.

Gregory, R., and L. Furby. "Auctions, Experi- ments, and Contingent Valuation." Public Choice 55(1987):273-89.

Grether, D. "Individual Behavior and Market Performance." Amer. J. Agr. Econ. 76(December 1994): 1079-83.

Harrison, G., R. Harstad, and E. Rutström. "Experimental Methods and the Elicitation of Values." Working paper, Department of Economics, University of South Carolina, 1995.

Hausman, J. "Specification Tests in Econometrics." Econometrica 46(November 1978): 1251-71.

Hayes, D., J. Shogren, J. Fox, and J. Kliebenstein. "Testing New Food Products with Experimental Markets." Psych. and Mkts. 13(July 1996):365-79.

Hayes, D., J. Shogren, S. Shin, and J. Kliebenstein. "Valuing Food Safety in Experimental Auction Markets." Amer. J. Agr. Econ. 77(February 1995):40-53.

Hoffman, E., D. Menkhaus, D. Chakravarti, R. Field, and G. Whipple. "Using Laboratory Experimental Auctions in Marketing Research: A Case Study of New Packaging for Fresh Beef." Mktg. Sci. 12(Summer 1993): 318-38.

Isaac, M., and J. Walker. "Information and Conspiracy in Sealed Bid Auctions." J. Econ. Behavior Org. 6, no. 20(1985):139-59.

Kagel, J. "Auctions: A Survey of Experimental Research." Handbook of Experimental Economics. J. Kagel and A. Roth, eds., pp. 50185. Princeton NJ: Princeton University Press, 1995.

Kagel, J., R. Harstad, and D. Levin. "Information Impact and Allocation Rules in Auctions with Affiliated Private Values: A Laboratory Study." Econometrica 55(November 1987): 1275-304.

McAfee, R.P., and J. McMillan. "Auctions and Bidding." J. Econ. Lit. 25(June 1987):699754.

McMillan, J. "Selling Spectrum Rights." J. Econ. Perspect. 8(Summer 1994):145-62.

Melton, B., W. Huffman, J. Shogren, and J. Fox. "Consumer Preferences for Fresh Food Items with Multiple Quality Attributes: Evidence from an Experimental Auction of Pork Chops." Amer. J. Agr. Econ. 78(November 1996):916-23.

Milgrom, P., and R. Weber. "A Theory of Auctions and Competitive Bidding." Econometrica 50(September 1982):1089-122.

Plott, C. "Laboratory Experimental Testbeds: Application to the PCS Auction." J. Econ. Manage. Strat. 6(Fall 1997):605-38.

- "Rational Individual Behavior in Mar- 
kets and Social Choice Processes." The Rational Foundations of Economic Behavior. K. Arrow, E. Colombatto, M. Perlman, and C. Schmidt, eds., pp. 225-50. London: Macmillan, and New York: St. Martin Press, 1996.

Roethlisberger, F., and W. Dickson. Management and the Worker. Cambridge MA: Harvard University Press, 1939.

Roosen, J., J. Fox, D. Hennessy, and A. Schreiber. "Consumers' Valuation of Insecticide Use Restrictions: An Application to Apples." $J$. Agr. and Resour. Econ. 23(December 1998): 367-84.
Rosenthal, R., and L. Jacobson. Pygmalion in the Classroom. Teacher Expectations and Pupils' Intellectual Development. New York: Holt, Rinehart, and Winston, 1968.

Shogren, J. "The Impact of Self-Protection and Self-Insurance on Individual Response to Risk." J. Risk Uncertainty 3(June 1990): 191-204.

Shogren, J., S. Shin, D. Hayes, and J. Kliebenstein. "Resolving Differences in Willingness to Pay and Willingness to Accept." Amer. Econ. Rev. 84(March 1994):255-70.

Vickrey, W. "Counterspeculation, Auctions and Competitive Sealed Tenders." J. Finan. 16(March 1961):8-37. 